\title{
Gavorník P, Dukát A, Gašpar L' et al. Antitrombocytová tromboprofylaxia artériových vaskulárnych chorôb a orgánovaskulárnych ischemických
}

\author{
chorôb.
}

Vnitř Lék 2017; 63(2): 124-132.

\section{Dopis MUDr. Jiřího Spáčila}

\section{Vážený pane šéfredaktore,}

po obdržení únorového čísla Vnitřního lékařství jsem s chutí nalistoval článek P. Gavorníka [1] uvedený jako doporučený postup. Po přečtení jsem byl zklamán. $\checkmark$ dlouhé úvodní části se autoři věnují názvosloví a etiologii chorob tepen. Jejich pojetí nemá oporu v jiných pracích, citujíjen svoje práce. V názvosloví si hrají se slovy (viz i název článku) a jejich klasifikace nemá praktický smysl. $\checkmark$ tab. 2 věnované etiologii není u většiny nemocí etiologie uvedena. Cévní choroby pojímají nezvykle velmi široce. Autoři se dále zabývají i organizací péče o tyto nemocné, která je značně vzdálená běžnému pojetí.

Je zřejmé, že autoři znají dobře problematiku jednotlivých skupin antitrombotik, nevytvářejí však skoro žádná doporučení. Uvádějí několikrát, že kyselina acetylsalicylová je standardní lék při primární i sekundární prevenci, dále pak správně uvádějí, že nyní se její použití v primární prevenci nedoporučuje.

\section{Odpověd' doc. MUDr. Petra Gavorníka}

Odporúčania vypracovávajú odborné lekárske inštitúcie. $V$ angiológii je to $v$ Slovenskej republike jednak Slovenská angiologická spoločnost' Slovenskej lekárskej spoločnosti (SAS SLS), ktorej vznik som inicioval 25. 3. 1993 a stal sa jej prvým prezidentom (1993-1994) [1], jednak Angiologická sekcia Slovenskej lekárskej komory (AS SLK), ktorej vznik som inicioval v roku 1994 a stal sa jej predsedom (doteraz). Ked’že podla vtedajšej legislatívy nemohla viest’ obidve odborné inštitúcie jedna osoba, musel som funkciu prezidenta SAS SLS odovzdat'. Už ako predseda 1. slovenského angiologického kongresu s medzinárodnou účast'ou (Tatranské Zruby 1993) som presadzoval koncepciu angiológie ako samostatnej špecializácie internej medicíny, ktorá sa venuje cievam a cievnym chorobám vo všetkých cievnych a orgánovaskulárnych oblastiach [2]. Samozrejme, že bez zasahovania do kompetencií orgánových špecializácií a vo vzájomnej kooperácii. Treba pripomenút', že AS SLK patrí medzi najaktívnejšie odborné sekcie SLK. Vypracováva, prepracováva a aktualizuje o.i. viaceré angiologické odporúčania, ktoré boli už opako-
Doporučení obvykle vypracovávají odborné společnosti. Zde není uvedeno, že by se na zpracování podílela Slovenská nebo Česká angiologická společnost. Domnívám se, že uvedení tohoto přehledu antitrombotik jako doporučeného postupu nebylo správné.

\section{Literatura}

1. Gavorník P, Dukát A, Gašpar L’ et al. Antitrombocytová tromboprofylaxia artériových vaskulárnych chorôb a orgánovaskulárnych ischemických chorôb . Vnitř Lék 2017; 63(2): 124-132.

MUDr. Jiří Spáčil, CSc.

$\triangle$ drjirispacil@seznam.cz

Cévní ordinace Spamed, s.r.o.

www.cevnordinace.cz

Doručeno do redakce 24. 4. 2017

vane publikované aj na stránkach časopisu Vnitřní lékařství. Angiologická sekcia SLK je v práci jasne uvedená. Z textu vyplýva, že ide o aktualizovanú verziu odporúčaní o antitrombocytovej tromboprofylaxii publikovanej naposledy v časopise Vnitřní lékařství (Vnitř Lék 2013; 59(11): 1081-1087). Výbor AS SLK si mimoriadne cení všetky doterajšie pripomienky, poznámky a rady viacerých kolegov, ktoré sa snaží zapracovat' do aktualizovaných odporúčaní. Podnet od MUDr. J. Spáčila, CSc. sme doteraz žiadny nedostali napriek nadchádzajúcemu už švrt'storočnému jubileu vzniku a činnosti SAS SLS i AS SLK.

Medicína dôkazov (EBM) doteraz poskytla relevantné informácie o antitrombocytovej tromboprofylaxii pri kardiovaskulárnej ischemickej chorobe, pri cerebrovaskulárnej ischemickej chorobe a pri končatinovocievnej ischemickej chorobe. Autori týchto odporúčaní sa však snažia zdôraznit', že orgánovaskulárnu angiologickú problematiku nemožno redukovat' iba na jeden či dva až tri orgány, ale na všetky orgány a tkanivá človeka (tab. 1 základného článku). Napokon neliečime ani 
orgán, ani diagnózu, ani chorobu, ale človeka. V odporúčaniach akcentujeme nevyhnutnost' presnej diferenciálnej diagnózy stenotizujúco-obliterujúcich artériových chorôb, pretože ateroskleróza je síce najčastejšou, ale rozhodne nie jedinou základnou kauzálnou chorobou (tab. 2 základného článku). To nie je ani o názvosloví, ani o klasifikácii, ale o esenciálnej potrebe presnej a včasnej komplexnej diagnózy v každodennej lekárskej klinickej praxi, bez ktorej nie je možná efektívna kauzálna racionálna prevencia a liečba. V tejto oblasti je aj medicína dôkazov zatial', žial', deficitná.

Takmer všetky doterajšie medzinárodné odporúčania sú orientované na manažment ischemickej choroby jedného orgánu pri ateroskleróze (monoorgánomonovaskulárna choroba), napr. končatinovocievna ischemická choroba na podklade aterosklerózy. Takýto pacient je však v klinickej praxi skôr raritný. Okrem aterosklerózy má spravidla aj iné kauzálne cievne choroby, napr. arteriolosklerózu, diabetickú mikroangiopatiu a d’alšie (tab. 2 základného článku) v rôznych kombináciách (monoorgánomultivaskulárna choroba) aj v závislosti od rizikových vaskulárnych faktorov. Kedže ateroskleróza je generalizovaná systémová artériová choroba, často sú ischémiou postihnuté okrem končatín aj srdce, mozog, prípadne d’alšie orgány (multiorgánomonovaskulárna choroba), v prípadoch s viacerými kauzálnymi cievnymi chorobami - multiorgánomultivaskulárna choroba. Niektoré artériové choroby vyžadujú špecifické kauzálne liečebné postupy (napr. pri Fabryho chorobe enzýmová substitučná liečba - ERT atd').

Ako postupovat' $v$ každodennej klinickej praxi pri týchto a iných reálne existujúcich zložitejších situáci- ách nám aktuálna medicína dôkazov (EBM) zatial' neposkytuje informácie, ale v odporúčaniach AS SLK z roku 2017 o antitrombocytovej tromboprofylaxii sú uvedené základné východiská pri rozhodovaní o začatí, o zmenách, o trvaní, o dávkovaní a o svičovaní jednotlivých antitrombocytových antitrombotík aj s odkazmi na najaktuálnejšie medzinárodné dokumenty a práce. Treba ich vnímat' $v$ kontexte $s$ predchádzajúcimi odporúčaniami AS SLK o antitrombocytovej tromboprofylaxii i v kontexte $s$ dalšími odporúčaniami AS SLK a s recenzovanými prácami Prvého angiologického pracoviska (PAP) v Bratislave (1974-2016) [3].

Sme presvedčení o správnosti našich princípov $v$ uvedených odporúčaniach a že budúcnost' potvrdí významné benefity pre pacienta pri ich zohladňovaní a dodržiavaní.

\section{Literatúra}

1. Gavorník P. Založenie samostatnej angiologickej spoločnosti v Slovenskej republike. Noninvas Cardiol (Cardiology Letters) 1993; 2: 136-137.

2. Gavorník P. I. slovenský angiologický kongres s medzinárodnou účastou v Tatranských Zruboch. Koncepcia angiológie. Noninvas Cardiol (Cardiology Letters) 1994; 3(Suppl 1): S1-S2.

3. Gašpar L. 40. výročie vzniku prvého klinického angiologického pracoviska na Slovensku. Monitor medicíny SLS 2014; 4: 41-42.

doc. MUDr. Peter Gavorník, PhD., mim. prof. \gavornik.peter@gmail.com

predseda AS SLK, emeritný vedúci lekár Prvého angiologického pracoviska (PAP), Bratislava, Slovenská republika

Doručeno do redakce 27. 4. 2017

\section{Korespondence ke článku}

\section{Jirkovská J. Možnosti efektivní edukace v diabetologii - návod pro edukátory.}

Vnitř Lék 2017; 63(3): 171-174.

\section{Dopis MUDr. Jana Brože}

\section{Vážený pane redaktore,}

se zájmem jsem si přečetl pěkný přehledný článek Jarmily Jirkovské [3] věnovaný diabetickým edukátorům. Dovolím si k němu poznámku. V článku není zmíněna jedna již ne úplně nová, ale stále moderní a více a více využívaná informační a komunikační cesta, a tou je internet. Ten umožňuje sestavení informační struktury zacílené na konkrétní typ problematiky, Ize ji tam jednoduše doplňovat a aktualizovat, je dostupná všem, kdo mají prístup na "sít" a informaci na ní lze hledat kdy- koliv, tedy i v př́padě, že ji pacient potřebuje aktuálně či je dokonce v tísni. Sociální sítě, tedy především Facebook, navíc umožňuji i mnohostrannou komunikaci jak mezi pacienty samotnými, tak i mezi pacienty a lékaři či edukátory a dávají možnost bezprostředně předávat zkušenosti či rady. V době velkého nedostatku edukačních materiálů pro pacienty $s$ diabetes mellitus 1. typu jsme vytvořili internetový portál www.diacentrum.cz. $V$ průběhu let 2008-2013 na něm více než $30 \mathrm{~s}$ (znamenajících, že návštěvník vyhledával nějakou informaci) 